\title{
Performance Evaluation of Selected Private Commercial Banks in Bangladesh
}

\author{
Tanbir Ahmed Chowdhury \\ Department of Business Administration, East West University \\ 43 Mohakhali C/A, Dhaka -1212, Bangladesh \\ Tel: 880-2-9882-308 Ext-244 E-mail: tanbir@ewubd.edu
}

Kashfia Ahmed

Department of Business Administration, East West University

43 Mohakhali C/A, Dhaka -1212, Bangladesh

Tel: 880-2-9882-308 Ext - 186 E-mail: kashfia_ahmed@hotmail.com

\begin{abstract}
In a developing country like Bangladesh the banking system as a whole play a vital role in the progress of economic development. In this paper we have tried to analyze the development and growth of Selected Private Commercial Banks of Bangladesh. It is observed that all the selected private commercial banks are able to achieve a stable growth of branches, employees, deposits, loans and advances, net income, earnings per share during the period of 2002-2006. Seven trend equations have been tested for different activities of the private commercial banks. Among them the trend value of branches, employees, deposits and net income are positive incase of all the selected banks. Square of correlation coefficient $\left(\mathrm{r}^{2}\right)$ has also been tested for all trend equations. The $\mathrm{r}^{2}$ of branches, deposits and net income is more than 0.5. It indicates the prospect of private commercial banks in Bangladesh is very bright.
\end{abstract}

Keywords: Bank, Commercial Bank, Loans, Deposit, Net Income

\section{Introduction}

\subsection{Banking Scenario in Bangladesh}

Banking system plays a very important role in the economic life of the nation. The health of the economy is closely related to the soundness of its banking system. In a developing country like Bangladesh the banking system as a whole play a vital role in the progress of economic development. A bank as a matter of fact is just like a heart in the economic structure and the Capital provided by it is like blood in it. As long as blood is in circulation the organs will remain sound and healthy. If the blood is not supplied to any organ then that part would become useless. So if the finance is not provided to agriculture sector or industrial sector, it will be destroyed. Loan facility provided by banks works as an incentive to the producer to increase the production. (http://www.blurtit.com/q197532.html)

Banking is now an essential part of our economic system. Modern trade and commerce would almost be impossible without the availability of suitable banking services. First of all, banking promotes savings. All manner of people, from the ordinary laborers and workers to the rich land owners and businessmen, can keep their money safely in banks and saving centers.

Secondly, banking promotes investments. Banks easily invest the money they get in industry, agriculture and trade. They either invest it directly or advance loans to other investors.

Thirdly, it is most through banks that foreign trade is carried on. Whether we export or import, it is through banks that money is transferred from one country to another. For example, bills of exchange and letters of credit are the regular ways banks use to transfer money.

A number of recent studies, however, indicate that the banking sector plays a more important role than it was believed earlier (World Bank, 1996; Almeyda)

In Bangladesh Sonali Bank is the largest among the Nationalized Commercial Banks (NCBs) while Pubali is leading in the private ones. Among the 12 foreign banks, Standard Chartered has become the largest in the country. Besides the 
scheduled banks, Samabai (Cooperative) Bank, Ansar-VDP Bank, Karmasansthan (Employment) Bank and Grameen bank are functioning in the financial sector. In Bangladesh the number of total branches of all scheduled banks is 6,038 as of June 2000. Of the branches, 39.95 per cent $(2,412)$ are located in the urban areas and 60.05 per cent $(3,626)$ in the rural areas. Of the branches NCBs hold 3,616, private commercial banks 1,214, foreign banks 31 and specialized banks 1,177 .

\subsection{Bangladesh Bank}

Bangladesh Bank (BB) has been working as the central bank since the country's independence. Its prime jobs include issuing of currency, maintaining foreign exchange reserve and providing transaction facilities of all public monetary matters. Bangladesh Bank (BB) regulates and supervises the activities of all banks. BB is also responsible for planning the government's monetary policy and implementing it thereby.

The BB has a governing body comprising of nine members with the Governor as its chief. Apart from the head office in Dhaka, it has nine more branches, of which two in Dhaka and one each in Chittagong, Rajshahi, Khulna, Bogra, Sylhet, Rangpur and Barisal.

\section{Category of Banks in Bangladesh}

\begin{tabular}{|c|c|c|}
\hline Category & Number of Banks & Number of Branches \\
\hline NCBs & 4 & 1214 \\
\hline Private Banks & 28 & 31 \\
\hline Foreign Banks & 12 & 1177 \\
\hline Development Banks & 5 & 1280 \\
\hline Other & 4 & 3616 \\
\hline
\end{tabular}

\section{Review of Literature}

With respect to the Performances of Bangladeshi Commercial Banking sector, foreign and national experts undertook number of studies. Some of the notable ones are; Bhattacharya (2007), Chowdhury and Islam (2007), Jahangir, Shill and Haque (2007), Chowdhury (2002), Siddique and Islam (2001), Al-Shamrnari and Salirni (1998), Avkiran (1997), Bhatt \& Ghosh (1992), Hossain \& Bhuiyan (1990), Swamy \& Vasudevan (1985), Ahmed \& Jamsheduzzaman (1985)

Bhattacharya (2007) pointed out that six major recent policy measures include: reduction of bank rate and lending rate, linking classified loans to large loan sanctioning; rationalization and merger of bank branches, measures for loan recovery, and demarcation of responsibilities between the management and the board and decision on cash reserve ratio.

Chowdhury and Islam (2007) stated that deposits and loan advances of Nationalized Commercial Banks (NCBs) are less sensitive to interest changes than those of Specialized Banks (SBs). So SBs should not make abrupt change in lending or deposit rates by following the NCBs. If NCBs change their lending or deposit rates, their deposits or loans and advances will be affected less than those of SBs. Moreover, deposits of NCBs have higher volume and higher volatility than those of SBs. On the other hand, loans advances of NCBs show a higher volume and higher volatility than those of SBs. However, SBs offer higher deposit rates and charge higher lending rates than NCBs. That is why the interest rate spread of SBs was higher than that of NCBs.

Jahangir, Shill and Haque (2007) stated that the traditional measure of profitability through stockholder's equity is quite different in banking industry from any other sector of business, where loan-to-deposit ratio works as a very good indicator of banks' profitability as it depicts the status of asset-liability management of banks. But banks' risk is not only associated with this asset liability management but also related to growth opportunity. Smooth growth ensures higher future returns to holders and there lies the profitability which means not only current profits but future returns as well. So, market size and market concentration index along with return to equity and loan-to-deposit ratio grab the attention of analyzing the banks' profitability.

Chowdhury (2002) observed that the banking industry of Bangladesh is a mixed one comprising nationalized, private and foreign commercial banks. Many efforts have been made to explain the performance of these banks. Understanding the performance of banks requires knowledge about the profitability and the relationships between variables like market size, bank's risk and bank's market size with profitability. Indeed, the performance evaluation of commercial banks is especially important today because of the fierce competition. The banking industry is experiencing major transition for the last two decades. It is becoming imperative for banks to endure the pressure arising from both internal and external factors and prove to be profitable.

Siddique and Islam (2001) pointed out that the Commercial Banks, as a whole, are performing well and contributing to the economic development of the country. The average profitability of all Bangladeshi banks collectively was $0.09 \%$ during 1980 to 1995 which means that a profit of TK 0.09 was earned by utilizing assets of TK 100 . In every aspect of 
profit, banking sector contributes the national economy as well as to the individual organization. Despite overall growth of the banking sector being positive, the performances of different categories of banks were not equally attractive.

According to Al-Shamrnari and Salirni (1998) profitability ratio especially return on equity (ROE) signals the earning capability of the organization. They also suggest that higher return on equity (ROE) ratio is appreciable as it is the primary indicator of bank's profitability and functional efficiency.

Avkiran (1997) stated that the details the process whereby multivariate interdisciplinary measures of potential to perform are integrated with performance measures to develop models of retail performance for bank branches. The predictive models use the key business drivers of a major trading bank as dependent variables. Independent variables explaining business drivers are the theorized potential variables that measure the capacity to generate retail business. The models allow a comparison between the predicted and actual levels of key business diverts, thus measuring unrealized performance. Findings can assist decision making during restructuring, branch closures or downsizing. The variables presented should be regarded as examples rather than universally accepted measures of branch performance.

Bhatt \& Ghosh (1992), observed that the profitability of commercial banks depend on several factors some of them are endogenous and some exogenous. The endogenous factors represent control of expenditure, expansion of banking business, timely recovery of loans and productivity. The exogenous factors consist of direct investments such as SLR (Statutory Liquidity Ratio), CRR (Cash Reserve Ratio) and directed credit programs such as region wise, population wise guidelines on lending to priority sectors. The regulated and restricted regime in the operation of banking system in terms of investment, credit allocation, branch expansion, interest rate determination and internal management eroded the productivity and profitability of commercial banks.

Hossain and Bhuiyan (1990) stated that there is no universally accepted operational definition of performance measures. In broad sense performance level of an enterprise can be measured by the extent of its organizational effectiveness. In the context of services rendered towards public the performance of an organization can be 2 viewed as 'the extent to which its work is carried out within established specifications for goods and services produced, to the general satisfaction of the clientele served, within given cost and time constraints, and in such a manner as to support or contribute to the achievement of the organization objectives.

In measuring performance level of a bank Swamy and Vasudevan (1985) used per employee, deposits, advances, profits, etc.

\section{Objectives of the Study}

The specific objectives of the study are as follows;

1) To present an overview of Private Commercial Banks of Bangladesh.

2) To appraise the performance of selected Private Commercial Banks of Bangladesh

3) To recommend remedial measures for the development of selected Private Commercial Banks of Bangladesh

\section{Scope \& Methodology of the study}

The present study has been carried out to evaluate the performance of selected private commercial banks of Bangladesh. The selected banks are Dutch Bangla Bank (DBBL), Dhaka Bank Ltd. (DBL), National Bank Ltd. (NBL), Prime Bank and Islami Bank Bangladesh Limited (IBBL). This study has been based mainly on data from secondary sources. The relevant data and information were collected from Stock Exchanges, Annual Reports of different commercial banks of Bangladesh, Bangladesh Bank, Securities and Exchange Commission and web sites of relevant commercial banks of Bangladesh etc. Relevant articles and literature in this context have also been consulted. In this article we analyzed last five years data of selected private commercial banks of Bangladesh. For evaluating the performance of selected private commercial banks of Bangladesh data has been analyzed through the various statistical measures like growth percentage, trend equation, square of correlation coefficient, correlation matrix etc.

Among the various straight line Trend Methods of Time Series Analysis the method of Least Square is most popular and widely used in practice. The method of least square can be used either to fit a straight-line trend or a parabolic trend. The straight line trend is represented by the equation $Y c=a+b$. Where, Yc denotes the trend values to distinguish them from the actual $\mathrm{Y}$ values. ' $\mathrm{a}$ ' is the $\mathrm{Y}$ intercept or the value of the $\mathrm{Y}$ variable when $\mathrm{X}=0$. ' $b$ ' represents the slope of the line of the amount of change in $\mathrm{Y}$ variable that if associated with a change of one unit in $\mathrm{X}$ variable. ' $\mathrm{X}$ ' variable in time series analysis represents time. The square of correlation coefficient $\left(r^{2}\right)$ is called the multiple determinations or squared multiple correlation coefficients. The coefficient of correlation is denoted by $r$. The value of $r$ lies between 0 and 1. The higher the $r^{2}$ the greater the percentage of the variation of $Y$ explained by the regression model, that is, the better the "goodness of fit" of the regression model to the sample observations. $r^{2}$ closer to zero, the worse the fit. 


\section{An overview of the Selected Private Commercial Banks of Bangladesh}

\subsection{DUTCH BANGLA BANK}

Dutch-Bangla Bank Limited (the Bank) is a scheduled commercial bank. The Bank was established under the Bank Companies Act 1991 and incorporated as a public limited company under the Companies Act 1994 in Bangladesh with the primary objective to carry on all kinds of banking business in Bangladesh. The Bank is listed with Dhaka Stock Exchange Limited and Chittagong Stock Exchange Limited. DBBL- a Bangladesh European private joint venture scheduled commercial bank commenced formal operation from June 3, 1996.

\subsection{Dhaka Bank Ltd. (DBL)}

A group of highly acclaimed businessmen of the country grouped together to responded to this need and established Dhaka Bank Ltd. in the year 1995. The bank was incorporated as a public limited company under the companies Act.1994. The bank started its commercial operation on July 05, 1995 with an authorized capital of TK. 1,000 million and paid up capital of the Bank stood at TK. 1,289,501,900 as on June 30, 2006. The total equity (capital and reserves) of the bank as on June 30, 2006 stood at TK. 2,188,529,224.

The Bank has 37 branches across the country and a wide network of correspondents all over the world. The bank offers the full range of banking and investment services for personal and corporate customers, backed by latest technology and a team of highly motivated officers and staff. In the effort to provide Excellence in Banking Services, the bank has launched Online Banking Service, Joined a countrywide shared ATM network and has introduced a co-branded credit card. A process is also underway to provide e-business facility to the bank's clientele through Online and home banking solutions.

\subsection{National Bank Ltd. (NBL)}

National bank has born as the first hundred percent Bangladeshi owned bank in Private sector. The then President of the People's Republic of Bangladesh Justice Ahsanuddin Chowdhury inaugurated the bank formally on March $28,1983$. NBL was first domestic bank to establish agency arrangement with the world famous Western Union in order to facilitate quick and safe remittance of the valuable foreign exchanges earned by the expatriate Bangladeshi nationals. NBL was also the first among domestic banks to introduce Master Card in Bangladesh. Since the very beginning, the bank exerted much emphasis on overseas operation and handled a sizeable quantum of homebound foreign remittances. The Bank established extensive drawing arrangement network with banks and exchange companies located in important countries of the world.

\subsection{Prime Bank}

Prime Bank Ltd. was created and commencement of business started on 17th April 1995. The sponsors are reputed personalities in the field of trade and commerce and their stake ranges from shipping to textile and finance to energy etc. Prime Bank Ltd. has already made significant progress within a very short period of its existence. The bank has been graded as a top class bank in the country through internationally accepted Capital adequacy, asset quality, management, earnings, liquidity, and sensitivity to market risk (CAMELS) rating. The bank has already occupied an enviable position among its competitors after achieving success in all areas of business operation. Prime Bank Ltd. offers all kinds of Commercial Corporate and Personal Banking services covering all segments of society within the framework of Banking Company Act and rules and regulations laid down by our central bank. Diversification of products and services include Corporate Banking, Retail Banking and Consumer Banking right from industry to agriculture, and real state to software. Prime Bank Ltd., since its beginning has attached more importance in technology integration. In order to retain competitive edge, investment in technology is always a top agenda and under constant focus. Keeping the network within a reasonable limit, our strategy is to serve the customers through capacity building across multi delivery channels. Our past performance gives an indication of our strength. We are better placed and poised to take our customers through fast changing times and enable them compete more effectively in the market they operate.

\subsection{Islami Bank Bangladesh Limited (IBBL)}

Bangladesh is one of the largest Muslim countries in the world. The people of this country are deeply committed to Islamic way of life as enshrined in the Holy Qur'an and the Sunnah. Naturally, it remains a deep cry in their hearts to fashion and design their economic lives in accordance with the precepts of Islam. The establishment of Islami Bank Bangladesh Limited on March 13, 1983, is the true reflection of this inner urge of its people, which started functioning with effect from March 30, 1983. This Bank is the first of its kind in Southeast Asia. It is committed to conduct all banking and investment activities on the basis of interest-free profit-loss sharing system. In doing so, it has unveiled a new horizon and ushered in a new silver lining of hope towards materializing a long cherished dream of the people of Bangladesh for doing their banking transactions in line with what is prescribed by Islam. With the active co-operation and participation of Islamic Development Bank (IDB) and some other Islamic banks, financial institutions, government 
bodies and eminent personalities of the Middle East and the Gulf countries, Islami Bank Bangladesh Limited has by now earned the unique position of a leading private commercial bank in Bangladesh.

\section{Performance Evaluation of Selected Private Commercial Banks of Bangladesh}

\subsection{Growth of Branches of Selected Private Commercial Banks}

Table: 1 shows the growth pattern of number of branches of selected banks. The growth of branches is highest in DBBL. But IBBL has highest number of branches i.e. 176. The lower growth percentage is in Prime Bank. Till 2005 Prime Bank had 50 branches but in 2006 Prime Bank had closed 9 of its branches.

\subsection{Growth of Employee of Selected Private Commercial Banks}

No of employees of selected banks have been shown in table: 2. The highest no of employees are working in IBBL i.e. 7459 and lowest in DBBL. The growth percentage is higher in DBBL and lowest in Prime Bank.

\subsection{Growth of Deposit of Selected Private Commercial Banks}

Table 3 shows growth pattern of deposits of selected commercial banks. It is observed from the table that the deposit is highest in IBBL that is TK 132,419,403,524 in 2006. The growth percentage of Prime Bank is highest that is $51.92 \%$ in 2006. In 2006 Growth percentage of Dutch Bangla Bank and Dhaka Bank is $47.25 \%$ and $46.12 \%$ in year 2006 respectively. The lowest growth percentage of deposit is in National Bank Ltd. that is $22.33 \%$ in 2006. During 2002 to 2006 every year deposit of Dhaka Bank, DBBL, NBL, Prime Bank and IBBL has increased from the previous year except 2005. So it is reflected from the table that the deposit of all the sele2cted banks have showed an increasing trend during the period of 2002-2006.

\subsection{Growth of Total Loans \& Advances of Selected Private Commercial Banks}

The growth pattern of total loan and advances of selected private commercial banks of Bangladesh are reflected from Table-4. It is reflected from the table that almost every year's loan and advances of selected private commercial banks of Bangladesh has increased from the previous year. The growth of loan and advances is more than $30 \%$ in Prime Bank, Dutch Bangla Bank and Dhaka Bank. The lowest growth observed in National Bank.

\subsection{Classified Loans of Selected Private Commercial Banks}

It is observed from table: 5 that the classified loan of DBBL, DBL and PBL is very low i.e. about $2 \%$. It seems that DBBL, DBL and PBL is able to manage credit efficiently as a result recovery is quite good. The percentage of classified loan in NBL and IBBL is above 5\%. It indicates percentage of classified loan is more in PBL and IBBL.

\subsection{Growth of Net Income of Selected Private Commercial Banks}

It is observed from the table: 6 that the net income of DBL, DBBL, NBL and IBBL has almost increased from the previous year during 2003 to 2006. It is also reflected that all the selected banks has earned net income in all the year during 2002 to 2006. Prime Bank has earned net income in every year but has failed to increase the net income from the previous year in 2003 and 2005. The growth rate of net income is stable and very high in NBL and DBL.

\subsection{EPS of Selected Private Commercial Banks}

It is reflected from the table: 7 that the EPS of all the selected commercial banks are very high during 2002 to 2006. It is observed that the average EPS of DBBL is more than $100 \%$. It is also reflected that average EPS of PB, DBL and NBL is more than $40 \%$. We have also observed that the EPS of IBBL is more than $400 \%$ during 2004 to 2006 . It is indicates the selected private commercial banks are earning very high profit. Highest growth of EPS in 2006 is IBBL and lowest is in Dhaka Bank. During 2004 IBBL have the highest growth of EPS and in 2003 NBL had lowest growth of EPS.

\subsection{Trend Equations of Selected Private Commercial Banks}

Table: 8 shows the summary of trend equation and $r^{2}$ of Branch expansion of selected private commercial banks. It is reflected from the table that trend equation of all the selected banks are positive and goodness of fit of all the equations are high i.e. more than 0.50. Incase of Islami Bank and Dhaka bank its very high i.e. more than 0.90.

Table: 9 shows the summary of trend equation and $r^{2}$ of employees of selected private commercial banks. It is reflected from the table that the trend equation of all the selected banks are positive. Goodness of fit of all the selected banks are high i.e. more than 0.80 except National Bank Ltd.

Table: 10 shows the summary trend equation and $\mathrm{r}^{2}$ of net income of selected private commercial banks. It is reflected from the table that the trend equation of all the selected banks are positive and goodness of fit of all the selected private commercial banks are very high i.e. more than 0.70 .

Table: 11 shows the summary trend equation and $\mathrm{r}^{2}$ of EPS of selected private commercial banks. It is reflected from the table that the trend equation of Dutch Bangla bank and National bank are positive and goodness of fit of Dutch Bangla Bank is very high i.e. more than 0.60 . 
Table: 12 shows the summary of the trend equation and $r^{2}$ of deposits of selected private commercial banks. It is reflected from the table that the trend equation of all the selected banks are positive and goodness of fit of all the equations are very high i.e. more than 0.85 .

Tabl2e: 13 shows the summary of the trend equation and $r^{2}$ of dividends of selected private commercial banks. It is reflected from the table that the trend equation of Dutch Bangla bank and National bank are positive and goodness of fit of Dutch Bangla Bank is very high i.e. more than 0.70 .

Table: 14 shows the summary of the trend equation and $r^{2}$ of Net Asset Value per Share of selected private commercial banks. It is reflected from the table that the trend equation of Dutch Bangla bank and National bank are positive and goodness of fit of Dutch Bangla Bank is very high i.e. more than 0.70.

\subsection{Correlation Matrix of Net Profit of Selected Private Commercial Banks}

Table2: 15 shows the correlation matrix for estimating interrelationships between chosen parameters of all the selected private commercial banks. From the correlation matrix we have observed the followings;

- $\quad$ Net Income has strong correlation with deposit, loans, branches and employees.

- $\quad$ Deposit has strong correlation with net income, loans, branches and employees.

- $\quad$ Loans have strong correlation with net income, deposit, branches and employees.

- $\quad$ Branches have strong correlation with net income, loans, deposits and employees.

- $\quad$ Employees have strong correlation with net income, loans, branches and deposits.

\section{Findings and Conclusion}

The journey of Private commercial banks has started in Bangladesh in the year 1982-1983. After commencement the private commercial play a vital role in the economic development of the country. The selected private commercial banks create employment opportunities for more than twelve thousand people. It has been observed that the net income of the selected private commercial banks have increased from the previous year during 2003 to 2006 . It is also reflected from the analysis that the EPS of all the selected commercial banks are very high during 2002 to 2006. It indicates the profitability of all the selected banks is quite satisfactory. Loans recovery rate indicated that the banks are able to manage their credit efficiently. Every year these banks open new branches and the IBBL has highest number of branches i.e. 176. It is observed that the classified loan of DBBL, DBL and PBL is very low i.e. about $2 \%$. It seems that DBBL, DBL and PBL is able to manage credit efficiently as a result recovery is quite good.

Seven trend equations have been tested for different activities of the private commercial banks. Among them the trend value of branches, employees, deposits and net income are positive incase of all the selected banks. Square of correlation coefficient $\left(r^{2}\right)$ has also been tested for all trend equations. The $r^{2}$ of branches deposits and net income is more than 0.5. It indicates the prospect of private commercial banks in Bangladesh is very bright.

Till 2005 the growth percentage of branches in case of National bank was zero. In 2006 Prime bank has closed 9 branches. In order to increase the activities and income these banks need to expand its new branches.

From the sequence of our analysis it is reflected that although the deposit of all the selected banks have showed an increasing trend during the period of 2002 to 2006, the total deposits of DBL, DBBL, NBL are not satisfactory in comparison to IBBL. So these banks need to increase their deposits.

It has been identified that although almost every year's loans and advances of selected private commercial banks have increased from the previous year, the growth rate of loans and advances is not satisfactory for NBL. So it should try to increase the growth rate.

DBBL need to increase its net income by increasing deposits, decreasing cost and expanding more branches. As the net income of Prime Bank is fluctuating, the bank should try to keep it at a stable point.

We are quite optimistic that if the given suggestions of this paper are implemented then the Banking sector may be able to overcome its present problems and may contribute in the rapid development of the economy of Bangladesh.

\section{References}

Al Shammari, M., and Salimi, M. (1998). Modeling the operating efficiency of banks, A parametric methodology. Journal of Logistic Information Management, Vol. 11.

Avkiran, N. K. (1997). Models of retail performance for bank branches: predicting the level of key business drivers. International Journal of Bank Marketing, Vol. 15, No. 6.

Bhatt, P. R., and Ghosh, R. (1992). Profitability of Commercial Banks in India. Indian Journal of Economics, India.

Chowdhury, A., (2002). Politics, Society and Financial Sector Reform in Bangladesh. International Journal of Social Economies, 29(12), $963-988$. 
Chowdhury, H. A., and Islam, M. S. (2007). Interest Rate Sensitivity of Loans and Advances: A Comparative Study between Nationalized Commercial Banks (NCBs) and specialized Banks (SBs). ASA University Review, Vol.1, No.1.

CPD Dialogue Report 49, (2002). Financial Sector Reforms in Bangladesh: The Next Round. Center for Policy Dialogue, Dhaka.

Hossain, M. K., and Bhuiyan, R. H. (1990). Performance Dynamics of Nationalized Commercial Banks in Bangladesh - The Case of Sonali Bank. Journal of Business Studies, University of Dhaka, Vol. XI, No. 1.

Jahangir, N., Shill, S., and Haque, M. A. J. (2007). Examination of Profitability in the Context of Bangladesh Banking Industry. ABAC Journal, Vol. 27, No. 2.

Siddique, S. H., and Islam, A. F. M. M. (2001). Banking Sector in Bangladesh: Its Contribution and Performance. Journal of Business Research, Jahangirnagar University, Vol. 3.

Swamy, M. R., and Vashudevan, S. V. (1985). A Text Book of Banking. S. Chand \& Company, New Delhi.

Table1. Number of Branches of Selected Private Commercial Banks

\begin{tabular}{|c|c|c|c|c|c|c|}
\hline \multirow{2}{*}{ SL } & Name of Banks & \multicolumn{5}{|c|}{ Number of Branches } \\
\hline & & 2002 & 2003 & 2004 & 2005 & 2006 \\
\hline 1 & Dhaka Bank Ltd. & 18 & 20 & 23 & 29 & 37 \\
\hline & Growth & & $11.11 \%$ & $15.00 \%$ & $26.09 \%$ & $27.59 \%$ \\
\hline 2 & Dutch Bangla Bank Ltd. & 17 & 17 & 19 & 28 & 39 \\
\hline 3 & Growth & & $0.00 \%$ & $11.76 \%$ & $47.37 \%$ & $39.29 \%$ \\
\hline 4 & National Bank Ltd. & 76 & 76 & 76 & 76 & 91 \\
\hline & Growth & & $0.00 \%$ & $0.00 \%$ & $0.00 \%$ & $19.74 \%$ \\
\hline 5 & Prime Bank Ltd. & 27 & 30 & 36 & 50 & 41 \\
\hline & Growth & & $11.11 \%$ & $20.00 \%$ & $38.89 \%$ & $-18.00 \%$ \\
\hline
\end{tabular}

Source: Compiled from different issues of Annual Report of Dhaka Bank Ltd., Dutch Bangla Bank Ltd., National Bank Ltd., Prime Bank Ltd. and Islami Bank Bangladesh Ltd.

Table 2. Employees of Selected Private Commercial Banks

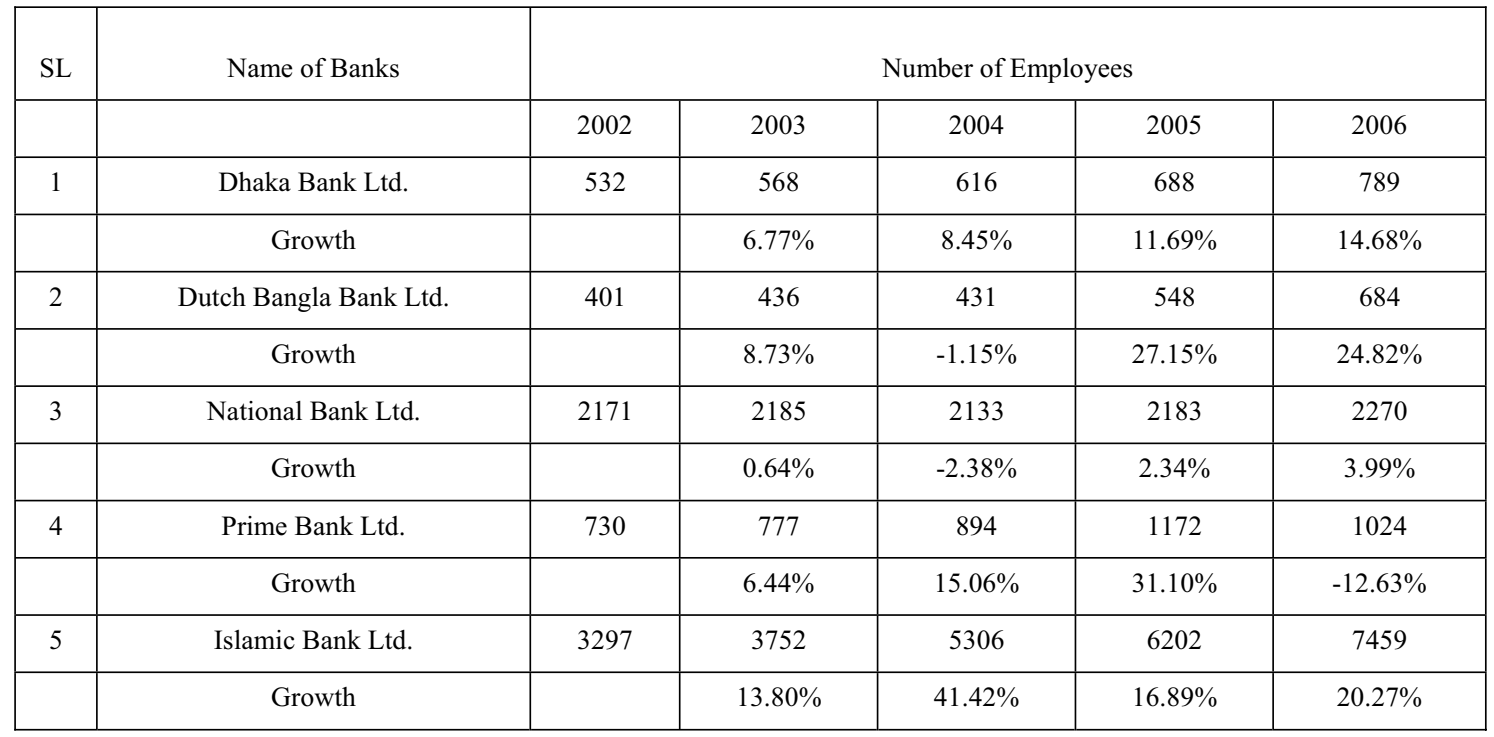

Source: Compiled from different issues of Annual Report of Dhaka Bank Ltd., Dutch Bangla Bank Ltd., National Bank Ltd., Prime Bank Ltd. and Islami Bank Bangladesh Ltd. 
Table 3. Deposits of Selected Private Commercial Banks

\begin{tabular}{|c|c|c|c|c|c|c|}
\hline \multirow[t]{2}{*}{ SL } & \multirow[t]{2}{*}{ Name of Banks } & \multicolumn{5}{|c|}{ Total Deposits (BDT) } \\
\hline & & 2002 & 2003 & 2004 & 2005 & 2006 \\
\hline \multirow[t]{2}{*}{1} & Dhaka Bank Ltd. & 14809967557 & 16850833278 & 22575365660 & 28438792427 & 41553551972 \\
\hline & Growth & & $13.78 \%$ & $33.97 \%$ & $25.97 \%$ & $46.12 \%$ \\
\hline \multirow[t]{2}{*}{2} & Dutch Bangla Bank Ltd. & 15975446123 & 17133812704 & 21067558418 & 27241107393 & 40111536968 \\
\hline & Growth & & $7.25 \%$ & $22.96 \%$ & $29.30 \%$ & $47.25 \%$ \\
\hline \multirow[t]{2}{*}{3} & National Bank Ltd. & 26276237646 & 27762117033 & 28973387115 & 32984053891 & 40350868324 \\
\hline & Growth & & $5.65 \%$ & $4.36 \%$ & $13.84 \%$ & $22.33 \%$ \\
\hline \multirow[t]{2}{*}{4} & Prime Bank Ltd. & 16172287880 & 20483225521 & 28069242650 & 36022455081 & 54724080584 \\
\hline & Growth & & $26.66 \%$ & $37.04 \%$ & $28.33 \%$ & $51.92 \%$ \\
\hline \multirow[t]{2}{*}{5} & Islamic Bank Ltd. & 55461621964 & 69941790927 & 87841013143 & 107779418134 & 132419403524 \\
\hline & Growth & & $26.11 \%$ & $25.59 \%$ & $22.70 \%$ & $22.86 \%$ \\
\hline
\end{tabular}

Source: Compiled from different issues of Annual Report of Dhaka Bank Ltd., Dutch Bangla Bank Ltd., National Bank Ltd., Prime Bank Ltd. and Islami Bank Bangladesh Ltd.

Note: $\quad$ US \$1 = BDT 69.35

Table 4. Total Loans \& Advances of Selected Private Commercial Banks

\begin{tabular}{|c|c|c|c|c|c|c|}
\hline \multirow{2}{*}{ SL } & Name of Banks & \multicolumn{5}{|c|}{ Total Loans \& Advances (BDT) } \\
\hline & & 2002 & 2003 & 2004 & 2005 \\
\hline 1 & Dhaka Bank Ltd. & 10761348979 & 12886688559 & 16538805141 & 23372450372 & 34048820675 \\
\hline & Growth & & $19.75 \%$ & $28.34 \%$ & $41.32 \%$ & $45.68 \%$ \\
\hline 2 & Dutch Bangla Bank Ltd. & 9391643291 & 11431318979 & 14976056619 & 20349422855 & 28325339997 \\
\hline & Growth & & $21.72 \%$ & $31.01 \%$ & $35.88 \%$ & $39.19 \%$ \\
\hline 3 & National Bank Ltd. & 21677960687 & 22257153235 & 22840436542 & 27020205114 & 32709675950 \\
\hline & Growth & & $2.67 \%$ & $2.62 \%$ & $18.30 \%$ & $21.06 \%$ \\
\hline 4 & Prime Bank Ltd. & 12686845330 & 16492224405 & 23219673305 & 31916112508 & 45010218048 \\
\hline & Growth & & $29.99 \%$ & $40.79 \%$ & $37.45 \%$ & $41.03 \%$ \\
\hline 5 & Islamic Bank Ltd. & 46280613393 & 59007490255 & 75858562224 & 93644154974 & 113575071129 \\
\hline & Growth & & $27.50 \%$ & $28.56 \%$ & $23.45 \%$ & $21.28 \%$ \\
\hline
\end{tabular}

Source: Compiled from different issues of Annual Report of Dhaka Bank Ltd., Dutch Bangla Bank Ltd., National Bank Ltd., Prime Bank Ltd. and Islami Bank Bangladesh Ltd.

Note: $\quad$ US \$1 = BDT 69.35 
Table 5. Classified Loan of Selected Private Commercial Banks

\begin{tabular}{|c|c|c|c|c|c|c|}
\hline \multirow[t]{2}{*}{ SL } & \multirow[t]{2}{*}{ Name of Banks } & \multicolumn{5}{|c|}{ Classified Loan } \\
\hline & & 2002 & 2003 & 2004 & 2005 & 2006 \\
\hline 1 & $\begin{array}{c}\text { Dhaka Bank Ltd } \\
.\end{array}$ & $2.48 \%$ & $3.26 \%$ & N/A & $1.51 \%$ & $1.64 \%$ \\
\hline 2 & Dutch Bangla Bank Ltd. & $0.60 \%$ & $0.36 \%$ & $0.16 \%$ & $1.76 \%$ & $2.88 \%$ \\
\hline 3 & National Bank Ltd. & N/A & N/A & $\mathrm{N} / \mathrm{A}$ & $5.58 \%$ & $6.01 \%$ \\
\hline 4 & Prime Bank Ltd. & $1.48 \%$ & $1.98 \%$ & $1.52 \%$ & $0.96 \%$ & $0.82 \%$ \\
\hline 5 & Islami Bank Bangladesh Ltd. & $6 \%$ & $6.8 \%$ & $6 \%$ & $3.25 \%$ & $3.43 \%$ \\
\hline
\end{tabular}

Source: Compiled from different issues of Annual Report of Dhaka Bank Ltd., Dutch Bangla Bank Ltd., National Bank Ltd., Prime Bank Ltd. and Islami Bank Bangladesh Ltd.

Note: N/A - Data not available

Table 6. Net Income of Selected Private Commercial Banks

\begin{tabular}{|c|c|c|c|c|c|}
\hline & \multicolumn{5}{|c|}{ Net Income (BDT) } \\
\hline & 2002 & 2003 & 2004 & 2005 & 2006 \\
\hline Dhaka Bank Ltd. & 234310726 & 269007381 & 357572894 & 462558947 & 580494670 \\
\hline Growth \% & & 14.81 & 32.92 & 29.36 & 25.50 \\
\hline Dutch Bangla Bank Ltd. & 177599990 & 210157591 & 236350352 & 367816801 & 362183665 \\
\hline Growth \% & & 18.33 & 12.46 & 55.62 & -1.53 \\
\hline National Bank Ltd. & 146191756 & 88122765 & 170017097 & 271667990 & 507492348 \\
\hline Growth \% & & -39.72 & 92.93 & 59.79 & 86.81 \\
\hline Prime Bank Ltd. & 418144625 & 375455447 & 611938344 & 568196286 & 1051890526 \\
\hline Growth \% & & -10.21 & 62.99 & -7.15 & 85.13 \\
\hline Islamic Bank Ltd. & 596430550 & 391405599 & 1013647225 & 1125821683 & 1400591591 \\
\hline Growth \% & & -34.38 & 158.98 & 11.07 & 24.41 \\
\hline
\end{tabular}

Source: Compiled from different issues of Annual Report of Dhaka Bank Ltd., Dutch Bangla Bank Ltd., National Bank Ltd., Prime Bank Ltd. and Islami Bank Bangladesh Ltd.

Note: US \$1 = BDT 69.35

Table 7. Earning Per Share of Selected Private Commercial Banks

\begin{tabular}{|c|c|c|c|c|c|}
\hline \multirow{2}{*}{ Name of Banks } & \multicolumn{5}{|c|}{ Earning Per Share (EPS) } \\
\hline & 2002 & 2003 & 2004 & 2005 & 2006 \\
\hline Dhaka Bank Ltd. & 61.77 & 50.65 & 53.86 & 37.66 & 45.02 \\
\hline Dutch Bangla Bank Ltd. & 87.86 & 103.97 & 116.93 & 181.97 & 179.18 \\
\hline National Bank Ltd. & 33.98 & 20.48 & 32.93 & 43.85 & 63.01 \\
\hline Prime Bank Ltd. & 69.69 & 53.64 & 61.19 & 32.47 & 60.11 \\
\hline Islamic Bank Ltd. & 0.93 & 203.86 & 439.95 & 407.20 & 405.26 \\
\hline
\end{tabular}

Source: Compiled from different issues of Annual Report of Dhaka Bank Ltd., Dutch Bangla Bank Ltd., National Bank Ltd., Prime Bank Ltd. and Islami Bank Bangladesh Ltd. 
Table 8 . Trend equation and $r^{2}$ of Branches

\begin{tabular}{|c|c|c|}
\hline Bank & Yc=a+bx & $\mathrm{r}^{2}$ \\
\hline Dhaka Bank Ltd. & $25.4+4.7 \mathrm{x}$ & .93 \\
\hline Dutch Bangla Bank Ltd. & $24+5.5 \mathrm{x}$ & .5 \\
\hline National Bank Ltd. & & $79+3 \mathrm{x}$ \\
\hline Prime Bank Ltd. & & .68 \\
\hline Islami Bank Bangladesh Ltd. & $36.8+4.8 \mathrm{x}$ & .99 \\
\hline
\end{tabular}

Table 9. Trend equation and $\mathrm{r}^{2}$ of no. of Employees

\begin{tabular}{|c|c|c|}
\hline Bank & Yc $=\mathrm{a}+\mathrm{bx}$ & $\mathrm{r}^{2}$ \\
\hline Dhaka Bank Ltd. & $638.6+63.4 \mathrm{x}$ & .96 \\
\hline Dutch Bangla Bank Ltd. & $500+67.8 \mathrm{x}$ & .84 \\
\hline National Bank Ltd. & $2188.4+19.6 \mathrm{x}$ & .38 \\
\hline Prime Bank Ltd. & $919.4+98.3 \mathrm{x}$ & .73 \\
\hline Islami Bank Bangladesh Ltd. & & .98 \\
\hline
\end{tabular}

Table 10. Trend equation and $\mathrm{r}^{2}$ of Net Income

\begin{tabular}{|c|c|c|}
\hline Bank & Yc $=\mathrm{a}+\mathrm{bx}$ & $\mathrm{r}^{2}$ \\
\hline Dhaka Bank Ltd. & $380.8+88.9 \mathrm{x}$ & .97 \\
\hline Dutch Bangla Bank Ltd. & $270.8+52.68 \mathrm{x}$ & .88 \\
\hline National Bank Ltd. & $236.7+90.61 \mathrm{x}$ & .73 \\
\hline Prime Bank Ltd. & $605.12+146.02 \mathrm{x}$ & .82 \\
\hline
\end{tabular}


Table 11. Trend equation and $r^{2}$ of EPS

\begin{tabular}{|c|c|c|}
\hline Bank & Yc=a+bx & \multicolumn{2}{|c|}{$\mathrm{r}^{2}$} \\
\hline Dhaka Bank Ltd. & $49.79-4.65 \mathrm{x}$ & .88 \\
\hline Dutch Bangla Bank Ltd. & $134+26.06 \mathrm{x}$ \\
\hline National Bank Ltd. & & .66 \\
\hline Prime Bank Ltd. & $38.85+8.14 \mathrm{x}$ & .20 \\
\hline Islami Bank Bangladesh Ltd. & $55.42-4.03 \mathrm{x}$ & .25 \\
\hline
\end{tabular}

Table 12. Trend equation and $\mathrm{r}^{2}$ of Deposits

\begin{tabular}{|c|c|c|}
\hline Bank & $\mathrm{Yc}=\mathrm{a}+\mathrm{bx}$ & $\mathrm{r}^{2}$ \\
\hline Dhaka Bank Ltd. & $\mathrm{Y}=24845.7+6507.51(\mathrm{x})$ & .91 \\
\hline Dutch Bangla Bank Ltd. & $\mathrm{Y}=24305.89+5837.94(\mathrm{x})$ & .87 \\
\hline National Bank Ltd. & $\mathrm{Y}=31269.33+3337.11(\mathrm{x})$ & .87 \\
\hline Prime Bank Ltd. & $\mathrm{Y}=31094.26+9264.28(\mathrm{x})$ & .93 \\
\hline Islami Bank Bangladesh Ltd. & $\mathrm{Y}=90688.64+19175.32(\mathrm{x})$ & .99 \\
\hline
\end{tabular}

Table 13. Trend equation and $\mathrm{r}^{2}$ of Dividend

\begin{tabular}{|c|c|c|}
\hline Bank & $\mathrm{Yc}=\mathrm{a}+\mathrm{bx}$ & $\mathrm{r}^{2}$ \\
\hline Dhaka Bank Ltd. & $\mathrm{Y}=15-1.5(\mathrm{x})$ & .22 \\
\hline Dutch Bangla Bank Ltd. & & .89 \\
\hline National Bank Ltd. & $\mathrm{Y}=22.4+1.5(\mathrm{x})$ & .72 \\
\hline Prime Bank Ltd. & $\mathrm{Y}=28+7(\mathrm{x})$ & .48 \\
\hline Islami Bank Bangladesh Ltd. & $\mathrm{Y}=23+6.5(\mathrm{x})$ & .41 \\
\hline
\end{tabular}


Table 14. Trend equation and $\mathrm{r}^{2}$ of Net Asset Value per Share

\begin{tabular}{|c|c|c|}
\hline Bank & $\mathrm{Yc}=\mathrm{a}+\mathrm{bx}$ & $\mathrm{r}^{2}$ \\
\hline Dhaka Bank Ltd. & $\mathrm{Y}=222.5-2.62(\mathrm{x})$ & .016 \\
\hline Dutch Bangla Bank Ltd. & $\mathrm{Y}=524.9+122.3(\mathrm{x})$ & .97 \\
\hline National Bank Ltd. & & .73 \\
\hline Prime Bank Ltd. & $\mathrm{Y}=447.9+48.58(\mathrm{x})$ & .55 \\
\hline Islami Bank Bangladesh Ltd. & $\mathrm{Y}=186.5+49.37(\mathrm{x})$ & .53 \\
\hline
\end{tabular}

Table 15. Inter- Parameter Correlation Matrix

\begin{tabular}{|c|c|c|c|c|c|}
\hline Variables & Net income & Deposit & Loans & Branches & Employees \\
\hline Net income & 1.000 & .869 & .873 & .630 & .708 \\
\hline Deposit & .869 & 1.000 & .999 & .891 & .934 \\
\hline Loans & .873 & .999 & 1.000 & 1.000 & .940 \\
\hline Branches & .630 & .891 & .897 & .970 & 1.000 \\
\hline Employees & .708 & .934 & .940 & & .970 \\
\hline
\end{tabular}

The covariance matrix is calculated and used in the analysis. 